\title{
Ionic Liquids Roles and Perspectives in Electrolyte for Dye-Sensitized Solar Cells
}

\author{
Ruwaida Asyikin Abu Talip ${ }^{1}$, Wan Zaireen Nisa Yahya ${ }^{1,2, * \mathbb{C}}$ and Mohamad Azmi Bustam ${ }^{1,2}$ (I) \\ 1 Chemical Engineering Department, Universiti Teknologi Petronas, Seri Iskandar 32610, Malaysia; \\ ruwaida_18003254@utp.edu.my (R.A.A.T.); azmibustam@utp.edu.my (M.A.B.) \\ 2 Centre of Research in Ionic Liquids, Universiti Teknologi Petronas, Seri Iskandar 32610, Malaysia \\ * Correspondence: zaireen.yahya@utp.edu.my; Tel.: +60-5-368-7584
}

Received: 1 July 2020; Accepted: 13 August 2020; Published: 15 September 2020

\begin{abstract}
Exploration of renewable energy, such as solar energy, is imminent not only to cater to the escalating energy demand but also to address the uprising environmental issues due to heavy usage of non-renewable fossil fuel. The dye-sensitized solar cells (DSSCs) which are considered as the third-generation solar cells, have a huge potential to be commercialized due to their low cost, simplicity in fabrication, and promising photon-to-electrical energy conversion efficiency. Nevertheless, a high cell efficiency can only be achieved when an organic solvent is incorporated into the formulation of the electrolyte, which is prone to evaporation and leakage. As a result, DSSCs become unsuitable for long-run usage due to thermal instability in the electrolyte. The early intention of incorporating ionic liquids (ILs) into the electrolyte was to curb the abovementioned problem and to enable the DSSCs to function as a sustainable energy device. As such, this article briefly reviews how ILs have been incorporated into the electrolyte formulation and the extent of how the ILs can affect the cell efficiency in various electrolyte states. The role of the ILs in a range of electrolytes is also highlighted. This sheds light on the true purpose of introducing ILs into DSSC electrolyte, which is to enhance the ionicity of the electrolyte.
\end{abstract}

Keywords: DSSC; electrolyte; ionic liquids

\section{Introduction}

The world population is still heavily reliant on fossil fuel to generate electricity. Fossil fuel refers to not only a non-renewable and non-sustainable type of resource that is finite and gradually depleting in amount, but also the combustion of it causes environmental pollution through the release of greenhouse gases. Hence, the exploration of renewable sources, such as solar energy, is vital to meet the increasing energy demand and to overcome the environmental issues caused by the heavy use of non-renewable fossil fuel [1]. This is in line with the United Nations' Sustainable Development Goals by 2030 agenda, which ascertains access to sustainable, reliable, and affordable modern energy for all [2].

Solar energy is a clean and the most abundantly available renewable energy. Only $10 \mathrm{~min}$ is required for the sun to irradiate the earth's surface to be equal to annual energy consumption. Photovoltaic technology is a method that converts solar energy to electrical energy [3]. Among the three generations of the photovoltaic cells, the third generation, particularly the dye-sensitized solar cells (DSSCs) have garnered much attention from researchers owing to the costly production and the environmental pollution that had arisen from the commercialized first and second generations of photovoltaic cells $[1,3]$.

The DSSCs have a huge potential to be commercialized due to low cost and simplicity in fabrication. They gained attention when the technology had a breakthrough with its cell efficiency that rose to $\sim 7-8 \%$. This was achieved by introducing nanometer-sized titanium oxide $\left(\mathrm{TiO}_{2}\right)$ to the working electrode 
surface in the year 1991 [4]. Before that, the maximum efficiency was stagnant at not more than $1 \%$. Since then, many studies have reported improvement in the DSSC's main components, such as the dye, the electrolyte, and the electrodes, in the attempt to increase cell efficiency. As a result, the cell efficiency has slowly increased, not drastically but significantly. This reflects the importance of improving every aspect of the DSSCs to gain high cell efficiency. In 2001, Nazeeruddin et al. [5] reported a cell efficiency of $10.4 \%$ by introducing a black dye (ruthenium-based) with better light-harvesting properties. In 2005, they [6] reported other ruthenium-based dyes in DSSCs, namely N719/N749 dye, which had resulted in high cell efficiency of $\sim 11-12 \%$. In 2018, a cell efficiency of $14.3 \%$ was recorded, which was the highest by far (under standard light intensity) by using cobalt (III/II) tris(1,10-phenanthroline) complex as redox couple in the electrolyte [7]. However, the high cell efficiency reported in the aforementioned study was attained through the use of volatile organic solvent as the solvent for the electrolytes. The most obvious solution to this instability issue is the complete elimination of liquid-based electrolyte and the incorporation of solid-state hole transport material (ss HTM) to take up the role of electrolyte and to form solid-state DSSC (ss-DSSC). Recently, an 11\%-cell efficiency was achieved by using an inorganic HTM $\left[\mathrm{Cu}\left(4,4^{\prime}, 6,60\right.\right.$-tetramethyl-2,2' -bipyridine)2](bis(trifluoromethylsulfonyl)imide) ${ }_{2}$ with $\left[\mathrm{Cu}\left(4,4^{\prime}, 6,6^{\prime}\right.\right.$ tetramethyl-2,2'-bipyridine) ${ }_{2}$ ](bis(trifluoromethylsulfonyl)imide) [8]. However, the noted efficiency was still lower than a liquid-based electrolyte, mainly due to the low conductivity nature of HTM and the inefficient HTM filling onto mesoporous $\mathrm{TiO}_{2}$, thus causing poor contact of the HTM with the mesoporous $\mathrm{TiO}_{2}$ [8]. Besides, the lack of stability data reported on the ss-DSSCs has raised concern on the long-term performance of ss-DSSCs.

An organic solvent, namely acetonitrile $(\mathrm{ACN})$, is commonly incorporated to form the liquid electrolyte for DSSCs. It has a low boiling point and easily vaporizes under heat stress. This is a major drawback that makes the DSSCs unsuitable for a long-run usage due to the thermal instability of the electrolyte, thus DSSCs are considered to be unfit as a sustainable energy device. Subsequently, higher boiling point solvents of more than $100{ }^{\circ} \mathrm{C}$ have been widely used to replace acetonitrile, namely valeronitrile, 3-methoxypropionitrile (MPN), N-methyl-2-pyrrolidone (NMP), ethylene carbonate, and methylene carbonate, to form a stable electrolyte [9]. Nevertheless, the DSSCs still face the problem of evaporation and leakage through the sealant at elevated temperatures [10]. This indirectly points out the difficulty for DSSCs to be commercialized for outdoor applications.

As a result, many studies have proposed a range of possible substitutes for organic solvent in the electrolyte. Among them, ionic liquids (ILs) have been identified as ideal materials. Different from other organic solvents, ILs possess almost negligible vapor pressure, high thermal stability, and non-flammability properties. Ionic liquids (ILs) refer to ionic compounds that exist as a liquid below $100^{\circ} \mathrm{C}$. This is due to the poor coordination between cations and anions that make up the IL compound $[1,11]$. These excellent properties have made ILs a sustainable solution to the organic solvent issue. They have quickly gained popularity and are largely accepted as a green solvent for various applications, apart from being a must-have-ingredient in an electrolyte. Not only limited to a liquid-based electrolyte, but also reported in numerous studies to be included in the formulation of solid and gel-based electrolytes. In these two latter cases, the ultimate purpose of using ILs is due to their exceptional ionicity [11].

Also known as designer's solvents, ILs are usually designed and synthesized for specific purposes. The combinations of various anions with cations, along with a range of pendants or functional groups, enable the synthesis of the desired ILs with specific properties. For example, the use of acidic halide ions resulted in ILs with higher thermal stability. Meanwhile, the cyclic-based ILs, particularly imidazolium-based ILs, have become the prevailing choice in studies concerning IL-based electrolytes for the past two decades. Among the members of the heterocyclic family, imidazolium has been commonly used as the cation for ILs due to several properties, such as lower viscosity, higher diffusivity, higher density, and higher thermal stability, when compared to pyridinium, pyrrolidinium, and ammonium [12]. Besides, the electrochemical windows of the ILs were mostly reported at about $4 \mathrm{~V}$, which appeared practical for many electrochemical devices, such as DSSCs [13]. 
For DSSCs to be commercialized, they should exhibit high efficiency and long-term stability. These two aspects are the technical challenges that demand further investigations. As a multi-component device, each DSSC aspect must be optimized. An electrolyte in DSSCs primarily serves as a medium for a redox reaction to occur. A well-articulated process contributes to cell efficiency [14]. Although the major concerns for DSSCs commercialization are poor long-term stability and low efficiency (due to the direct connection with electrolyte component), surprisingly, only $11 \%$ of all studies related to electrolyte had probed into DSSCs until the year 2015 [15]. The search for an ideal solvent for DSSCs electrolytes is crucial as it determines the efficiency of fabricated DSSCs.

A review by Iftikhar et al. emphasized on the progress of different types of electrolytes for DSSCs and discussed how far the introduction of a variety of materials to develop DSSCs electrolyte had improved cell performance and long-term stability [15]. Meanwhile, Lee and Ho in their short review focused on the recently emerging poly(ILs)-based electrolytes (considered as a quasi-solid or solid polymer) which used ILs as the monomer block and discussed in length their prospects [16]. Mahmood et al. in 2015 [17] shed some light on how far the progress of quasi-solid state electrolytes DSSCs (qs-DSSCs) with extra attention given on how this type of electrolyte was beneficial to obtain DSSCs with better thermal stability and cell efficiency. A review by Yusuf et al. [18] in 2017 was focused on how ILs have indeed enhanced the polymer electrolytes and how the incorporation of ILs have affected the performance of various electrochemical devices, such as batteries, supercapacitors, fuel cells, and DSSCs. Quite different from other reviews, Muhammad [19] concentrated on how the physical properties of quasi solid-state polymer electrolytes were characterized. An in-depth discussion on the role of ILs in DSSCs to the best knowledge of the authors has not yet been reviewed.

Therefore, this present review has a two-fold objective. First, different ILs that have been incorporated into different types of DSSCs electrolytes were explored. Second, an insight on to what extent ILs can solve the issues that arise due to the usage of organic solvents, as well as the implications on the DSSCs' efficiency is discussed. As such, this present review revolves on how ILs were included as part of the electrolyte for DSSCs, and how the ILs helps to enhance the transport properties of the electrolyte.

\section{Principle of Dye-Sensitized Solar Cells (DSSCs)}

The major components that make up a DSSC are two sheets of glass coated with a transparent conductive oxide layer (TCO), dye-sensitized particles that are adsorbed on the nanoparticles of $\mathrm{TiO}_{2}$ layer attached on one of the TCOs, and electrolyte that is filled in between the two TCOs (see Figure 1) [20]. The substrates such as glass are coated with a transparent conductive oxide layer (TCO) to ensure high conductivity and to maximize photon absorption. The TCO with the layer of semiconductor $\mathrm{TiO}_{2}$ sensitized by dye particles denotes the anode (photoelectrode), whilst the other one coated with platinum is the cathode (counter electrode).

A few steps are involved to convert photon energy to electrical energy, as illustrated in Figure 2. The first step refers to the activation step occurs when photon energy is absorbed by the dye sensitizer particles. The absorption leads to photoexcitation in the electron of dye molecule from the highest occupied molecular orbital (HOMO) to the lowest occupied molecular orbital (LUMO) (step 1) (see Equation (1)). Next, the electron is injected into the conduction band of the semiconductor, $\mathrm{TiO}_{2}$ (step 2) (see Equation (2)). The electron flows to the counter electrode through the external circuit, in which electrical energy is generated in step $3[14,21,22]$. 


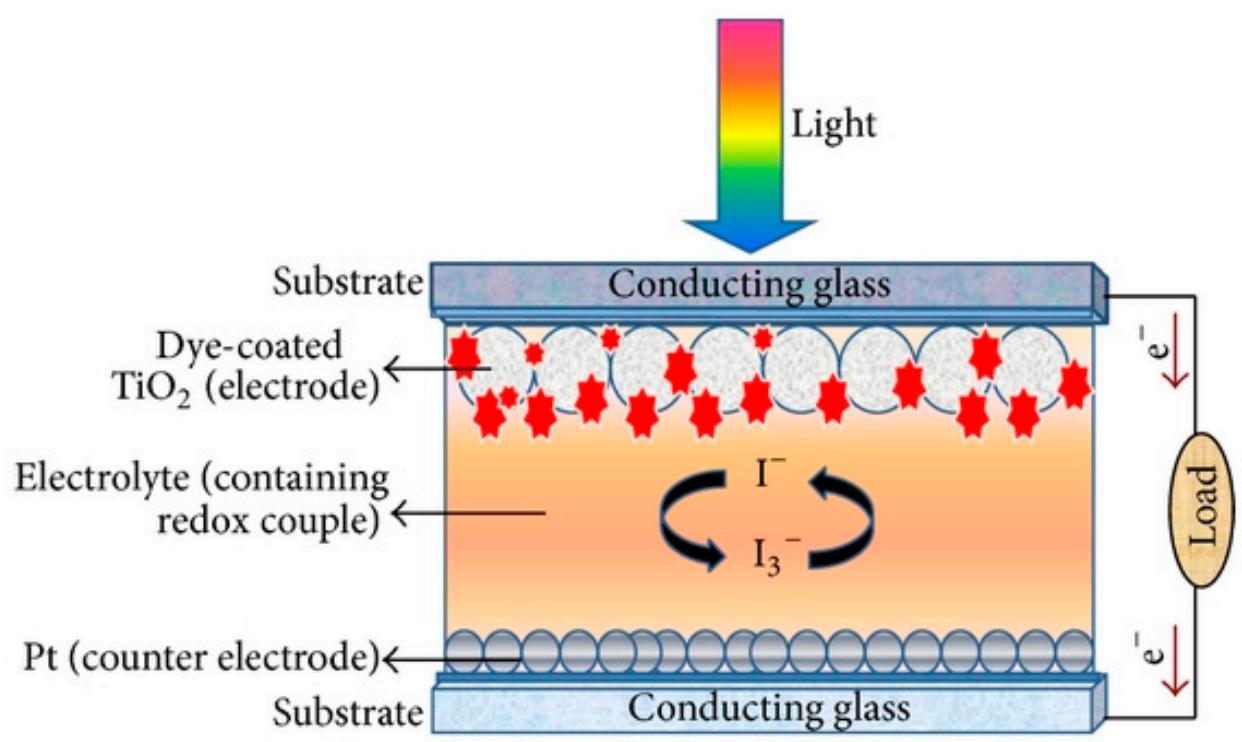

Figure 1. Basic components of dye-sensitized solar cells (DSSC). Reprinted from Kushwaha et al. [20].

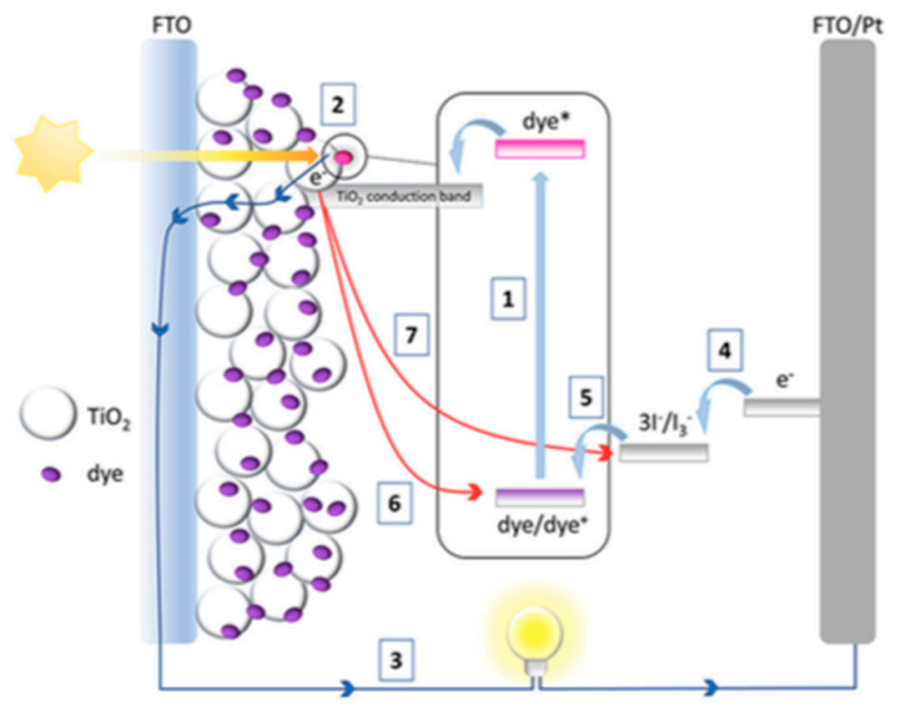

Figure 2. The architecture and operation principals of a typical DSSC at different steps 1-7. Reprinted from Carella et al. [21].

The regeneration of dye into its reduced state is performed through redox reaction (step 5). Once the triiodide $\left(\mathrm{I}_{3}{ }^{-}\right)$in the electrolyte receives the electron from the counter electrode (step 4) (see Equation (3)), it reduces into iodide $\left(\mathrm{I}^{-}\right)$. The iodide, $\mathrm{I}^{-}$, oxidizes back into $\mathrm{I}_{3}{ }^{-}$. The electron from redox reaction diffuses back into the dye molecule for the electron to be in its original HOMO level and the dye to be in its original energy level (step 5) (see Equation (4)) [14]. The steps occur repeatedly to result in a continuous flow of electron through the circuit to generate current.

$$
\begin{gathered}
\mathrm{D} / \mathrm{TiO}_{2}+h v \rightarrow \mathrm{D}^{*} / \mathrm{TiO}_{2} \\
\mathrm{D}^{*} / \mathrm{TiO}_{2} \rightarrow \mathrm{D}^{+} / \mathrm{TiO}_{2}+\mathrm{e}^{-} / \mathrm{TiO}_{2}
\end{gathered}
$$

Redox Couple ${ }^{+}+\mathrm{e}^{-} /$Counter electrode $\rightarrow$ Redox Couple

$$
\mathrm{D}^{+} / \mathrm{TiO}_{2}+\text { Redox Couple } \rightarrow \mathrm{D} / \mathrm{TiO}_{2}+\text { Redox Couple }{ }^{+}
$$


However, an undesired process called 'electron recombination' may occur throughout the DSSC's operation. This recombination of the injected electron with the oxidized sensitizer (step 6) or oxidized triiodide species $\left(\mathrm{I}_{3}{ }^{-}\right)$(step 7) may cause the absorbed photon to be unusable for electrical generation, thus deteriorating cell performance [21,22]. Although all components play their important role, each of them may affect the photon-to-electrical energy conversion efficiency, $\eta$, of the fabricated DSSCs. The correlation is represented in Equation (5) [22]:

$$
\eta=J_{\mathrm{sc}} \times V_{\mathrm{oc}} \times \mathrm{FF} / \mathrm{I}_{0}
$$

where $\mathrm{J}_{\mathrm{sc}}$ is short circuit current density, $\mathrm{V}_{\mathrm{oc}}$ signifies open-circuit voltage, FF denotes fill factor of the solar cell, and $\mathrm{I}_{0}$ is the incident current, most commonly at standard $100 \mathrm{~mW} / \mathrm{cm}^{2}$ illumination. The fill factor can be obtained by multiplying the voltage with the photocurrent that results from the maximum electrical power gained by the cell. The $\mathrm{J}_{\mathrm{sc}}$ is directly affected by the absorption ability of the dye-sensitizer. Hence, to increase this term, a dye with high light-harvesting capacity or high molar coefficient is needed. As for $\mathrm{V}_{\mathrm{oc}}$, it is affected by the difference in the energy levels between the redox potential of the redox couple and the conducting band of the semiconductor. As for the electrolyte, apart from the $\mathrm{V}_{\mathrm{oc}}$, it is also indirectly affecting the $\mathrm{J}_{\mathrm{sc}}$ as the recombination process may occur in the electrolyte. The three components of the electrolyte are the solvent, the redox couple, and can include additives. The redox couple acts as the dye regenerator. An efficient dye regeneration is highly desirable as it increases both the redox potential of the redox couple and the value of the $\mathrm{V}_{\mathrm{oc}}$. The classical choice of redox couple is iodide/triiodide pair. Lithium iodide or iodide-based ILs are the common sources of iodide ion. Inclusion of equimolar iodine into iodide forms triiodide ion. Despite being the most used redox couple, unfortunately, the limitation of the iodide/triiodide pair lies in its small redox potential difference with $\mathrm{TiO}_{2}$, thus limiting the $\mathrm{V}_{\mathrm{oc}}$. Therefore, the introduction of alternative redox couples using transition metals, such as cobalt and copper, have been largely reported to address the shortcoming of the iodide/triiodide pair $[10,14]$. The highest recorded cell efficiency $(14.3 \%)$ at present uses cobalt (III/II) tris(1,10-phenanthroline) complex as the redox couple, which gave a far higher value than that using the iodide/triiodide pair (11.5\%) [10]. Many had reported that the inclusion of additives, such as nitrogen heterocyclic compound, could increase the conducting band of the anode, thus resulting in a higher $\mathrm{V}_{\mathrm{oc}}$. The solvent plays a critical role as it is primarily the medium that dissolves both the redox couple and the additive, which enables the redox reaction to occur, to recover the dye, and to allow the electron transfer to occur in the DSSCs [21,22]. Due to these roles, the electrolyte can greatly affect the DSSCs by dictating the recombination kinetics of excited electrons with the redox species that exert impact on the electrochemical potential of $\mathrm{TiO}_{2}$.

Put simply, the selection of materials that make up the electrolyte is crucial as the materials contribute to the overall conversion efficiency and stability of DSSCs [23]. The electrolyte needs to have high ionic conductivity and thermal stability. Li et al. [24] asserted that the two main processes that lower the cell efficiency are the undesired recombination of the excited electron with triiodide ion, as well as the slow rate in the regeneration of dye particles due to low diffusion coefficient of the redox couple and low ionic conductivity. Both of these issues stem from the electrolyte components. Hao et al. [25] claimed that a successful redox shuttle must reduce the dye cation particles before recombining with the excited electron at the photoanode. Kinetically, a fast dye regeneration reaction retards the recombination process as the desired and undesired processes have their rates as depicted in Figure 3 [26]. 


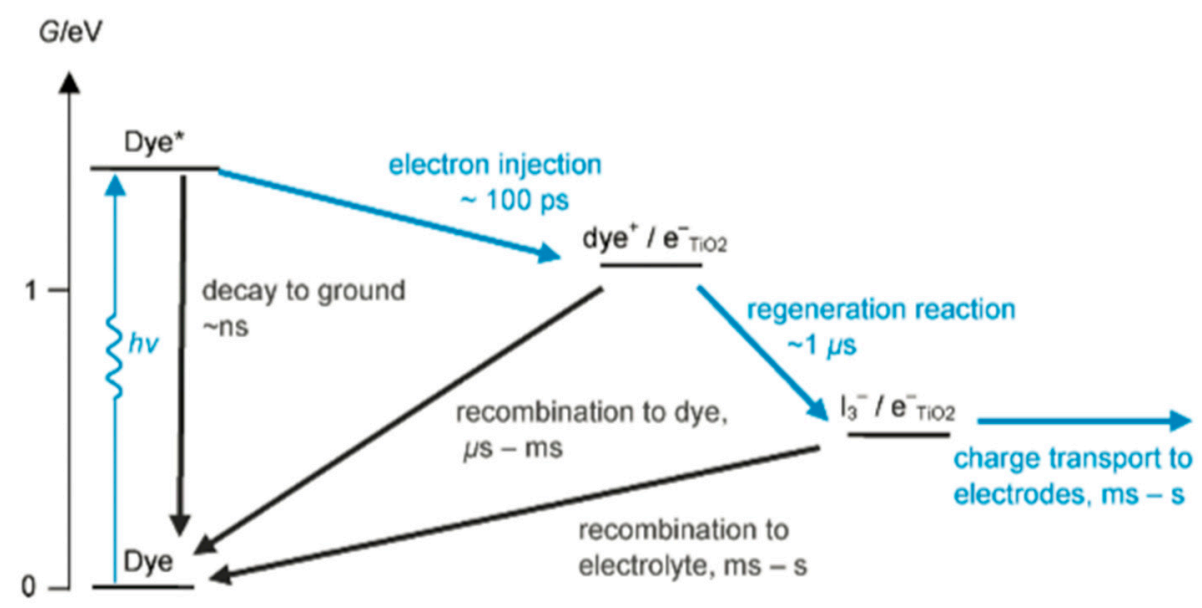

Figure 3. State diagram representation of the kinetics of DSSC function. Reprinted with permission from Listorti et al. [26]. Copyright: American Chemical Society

\section{Ionic Liquids in Liquid Electrolyte for DSSC}

The three types of electrolytes for DSSCs are liquid, solid, and quasi solid electrolytes. In liquid electrolyte, $\mathrm{ACN}$ is the main solvent by far that offers the highest cell efficiency [6]. Being the simplest organic nitrile, ACN (low in viscosity of $0.536 \mathrm{mPa} \cdot \mathrm{s}$ at $25^{\circ} \mathrm{C}$ ) dissolves other electrolyte components including redox couple and additive, to enable the redox reaction to occur. Mass transport is governed by the gradient diffusions of the species present in the electrolyte. A solvent with low viscosity enhances the diffusion coefficient of the redox couple, besides allowing high ionic conductivity, and more importantly, high cell efficiency [12].

Other types of nitrile-based organic solvent, such as 3-methoxypropionitrile (MPN) and valeronitrile $(\mathrm{BuCN})$ with boiling points higher than $\mathrm{ACN}$, had been tested as solvents in the electrolyte for DSSCs. The drawback of using an organic solvent as mentioned earlier is that it easily vaporizes despite having a high boiling point, thus unsuitable for long-term usage as the cell is bound to experience solvent evaporation over time. As a result, ILs were introduced to solve the problem posed by organic solvents. Ionic liquids (ILs) have an unprecedented high boiling point with negligible vapor pressure. For each study reviewed here, the function of ILs is translated into two; additives and solvent.

Nazeeruddin et al. [6] used a standard dye, N719, with 0.60 M 1-buty-3-methylimidazolium iodide (BMII), $0.03 \mathrm{M}$ iodine $\left(\mathrm{I}_{2}\right), 0.10 \mathrm{M}$ guanidinium thiocyanate, and $0.50 \mathrm{M}$ tert-butylpyridine in a mixture of $\mathrm{ACN}$ and $\mathrm{BuCN}$ (volume ratio: 85:15) to prepare the electrolyte components for DSSCs. The cell efficiency recorded was very promising, at $11.3 \%$. Next, Gao et al. [27] proposed to solve the dependability on volatile ACN by increasing the molar extinction coefficient by using C101 dye in hope that, by increasing the absorption capacity of the dye, both $\mathrm{J}_{\mathrm{sc}}$ and cell efficiency can be enhanced. They also studied the selection of different solvents to determine their impact on cell efficiency. By employing the same dye, $\mathrm{C} 101$, the use of highly volatile $\mathrm{ACN}$ resulted in $10.5 \%$ cell efficiency. Meanwhile, the use of a less volatile solvent (MPN) and non-volatile IL (1-ethyl-3-methylimidazolium tetracyanoborate (EMITCB)) resulted in $9.0 \%$ and $7.4 \%$ cell efficiencies, respectively. Among all three, the cell with EMITCB displayed outstanding thermal stability, when compared to cells with ACN and MPN. The variance in the efficiency signified the importance of the diffusion coefficient. The increase in dye absorption capacity alone is inadequate to enhance cell efficiency. Electron impedance spectroscopy data revealed that both $\mathrm{ACN}$ and MPN solvents led to higher diffusion coefficients when compared to EMITCB. This clearly denotes the connection of diffusion coefficients with cell efficiency and viscosity. Additionally, the viscosity also determines the rate of the ion diffusion of the redox ions to allow for the dye regeneration. As for the imidazolium-based IL (EMITCB), its high viscosity, in comparison to organic solvents (ACN and MPN), impeded the ionic diffusion and lowered the diffusion coefficient. The transient photoelectrical measurement data showed a higher recombination rate for the solvent-free 
IL electrolyte when compared to the organic solvent-based electrolyte. The study suggested that this was due to the viscous nature of the IL-based electrolyte, which had low ionic diffusion that led to a high concentration of triiodide anion near the photoanode that further promoted back electron transfer.

Kang et al. [28] reported the usage of pure IL as a solvent of the electrolyte for DSSCs. Novel IL, 1-vinyl-3-heptylimidazolium iodide (VHpII) was used as the solvent for the electrolyte. The thermogravimetric analysis revealed that the VHpII was stable for thermal stress up to $250{ }^{\circ} \mathrm{C}$ and non-volatile at $150{ }^{\circ} \mathrm{C}$, thus suggesting the low probability of photovoltaic cell leakage due to long exposure to irradiation, which was suffered by the organic solvent-based DSSCs electrolytes. The conversion efficiency was reported to be $2.63 \%$. Nonetheless, the addition of lithium iodide (LiI) as part of the electrolyte had increased the efficiency to $3.63 \%$. The obvious increase in $\mathrm{J}_{\mathrm{sc}}$ value upon the addition of LiI was observed from $6.63 \mathrm{~mA} \cdot \mathrm{cm}^{-2}$ (before addition) to $9.61 \mathrm{~mA} \cdot \mathrm{cm}^{-2}$ (after addition). The conduction band of $\mathrm{TiO}_{2}$ had positively shifted, thus enhancing the electron injection from the excited dye molecules. On the contrary, the addition of LiI in the electrolyte had increased the dark current that implied the loss of a large number of electrons at the conduction band due to recombination. This is portrayed in the decrease in $\mathrm{V}_{\mathrm{oc}}$. The $\mathrm{Li}^{+}$cations had better adsorption on the $\mathrm{TiO}_{2} /$ electrolyte surface when compared to $\mathrm{VHpI}^{+}$cations, which were more hydrophobic and had less adsorption on the interface. The back-electron transfer (recombination) was enhanced by the presence of $\mathrm{Li}^{+}$cations and had decreased the $\mathrm{V}_{\mathrm{oc}}$, when compared to the presence of only $\mathrm{VHpI}^{+}$cations. This seemed to contradict what observed by Gao et al. [27].

The low cell efficiency reported with the usage of ILs alone in the electrolyte stemmed from inefficient mass transfer due to the high viscosity nature of ILs. Hence, many efforts have been made to reduce the viscosity of IL by adding another IL. This had been performed to achieve a free-organic solvent for DSSCs. This combination of ILs is called binary or tertiary, depending on how many ILs are involved in obtaining the mixture with new physical properties. Papageorgiou et al. [29] reported one of the earliest attempts to obtain better photoconversion efficiency by introducing low viscosity ILs mixtures. This was achieved by mixing two or more ILs of different viscosity values. In the study, the viscosity of 1-hexyl-3-methylimidazolium iodide (HMImI) was reduced by adding a low viscosity IL namely 1-ethyl-3-methylimidazolium triflate (EMImTf). The said mixture in the electrolyte of DSSCs resulted in a better photo energy conversion efficiency when compared to HMImI alone. The addition of EMImTf to HMImI had increased the diffusion coefficient of triiodide by $1.6 \%$, in comparison to the use of HMImI alone, wherein the conversion efficiency was $~ 7 \%$.

Mhd Yusof and Yahya [30] had attempted to overcome the low mass transportation in viscous IL by adding low viscosity 1-butyl-3-methylimidazolium thiocyanate (BMISCN) (56 mPa.s) into IL of higher viscosity, 1-propyl-3-methylimidazolium iodide(PMII) (336 mPa.s). These two ILs were mixed at four different ratios to study their effect on cell efficiency. As a result, the mixture ratio of PMII to BMISCN at 1:0.75 gave the highest power conversion efficiency at $1.89 \%$. Although the mixture ratio of PMII to BMISCN at 1:1 gave the lowest viscosity (68 $\mathrm{mPa} \cdot \mathrm{s})$ with the highest triiodide diffusion coefficient, the power conversion efficiency was only $1.52 \%$. This indicated that the viscosity and diffusion coefficient are not the only factors that determine cell efficiency.

In the year 2008, Cao et al. [31] employed the classic choice of redox couple; $\mathrm{I}_{3}{ }^{-} / \mathrm{I}^{-}$and explored several known ILs to prepare an efficient electrolyte for DSSCs. They had assessed several ILs of different density, conductivity, and fluidity to combine with $\mathrm{I}_{3}-/ \mathrm{I}^{-}$redox couple in forming an electrolyte for DSSCs. The ILs employed were 1-hexyl-3-methylimidazolium iodide (HMII), 1-butyl-3-methylimidazolium iodide (BMII), 1-propyl-3-methylimidazolium iodide (PMII), as well as a mixture of 1-ethyl-3-methylimidazolium iodide, 1,3-dimethylimidazolium iodide, and 1-allyl-3-methylimidazolium iodide (EMII/DMII/AMII). The study highlighted the importance of using low viscosity redox couple (triiodide/iodide). As a result, EMII/DMII/AMII-based electrolyte of DSSC displayed better power conversion efficiency when compared to single ILs (HMII, BMII, and PMII), mainly because the mixture had high fluidity and low density. 
Often, the connection between ILs structures and their properties is emphasized in the reviewed studies. This is to obtain an IL with specific properties, such as low viscosity. This is an alternative to obtain ILs with low viscosity without adding another IL or solvent. This property is greatly highlighted due to its direct connection to ionic conductivity. Son et al. [32] examined the correlation between the substituents on imidazolium cation that made up the imidazolium-based IL to assess the performance of DSSCs, especially the photocurrent-voltage characteristic. A series of ILs based on iodide anion and the cations namely 1,3-diethylimidazolium (DEII), 1-ethyl-3-methylimidazolium (EMII), 1-ethyl-3-vinylimidazolium (EVII), 1-(4-acetophenyl)-3-ethylimidazolium (AcePheEII), and 1-hexyl-3-methylimidazolium (HMII) were synthesized. The study had evaluated the $\mathrm{J}_{\mathrm{sc}}, \mathrm{V}_{\mathrm{oc}}, \mathrm{FF}$, and the power conversion efficiency (h) of the ILs. It was found that the variety of the substituents attached to the cations had greatly affected the $\mathrm{J}_{\mathrm{sc}}$. The study suggested that the decrease in the size of substituent increased the $\mathrm{J}_{\mathrm{sc}}$. For instance, the DEII and HMII that contained diethyl alkyl and hexyl-methyl alkyl chains gave $\mathrm{J}_{\mathrm{sc}}$ values of 12.5 and $11.1 \mathrm{~mA} \cdot \mathrm{cm}^{-2}$, respectively. As for the diffusion coefficients of the redox couple $\left(\mathrm{I}^{-}\right.$and $\left.\mathrm{I}_{3}{ }^{-}\right)$, the smaller size of the substituent resulted in a more rapid ion diffusion and led to higher $\mathrm{J}_{\mathrm{sc}}$. Consequently, a larger substituent caused a larger charge transfer resistance, thus low $\mathrm{J}_{\mathrm{sc}}$. As a result, the solar-to-electricity conversion efficiencies of DEII and HMII were $4.8 \%$ and $4.2 \%$, respectively.

In another study, several imidazolium-based ILs were synthesized and combined with $0.1 \mathrm{M} \mathrm{LiI}$ and $0.05 \mathrm{M} \mathrm{I}_{2}$ in MPN to prepare the electrolyte component for DSSCs [33]. The use of MPN (with a high boiling point) was meant to increase the ionic properties of the electrolyte, which reflected an attempt to replace the can. The imidazolium structure was attached with different lengths of alkyl chains. It was found that the imidazolium-based ILs with the alkyl chain of four carbons showed $\mathrm{V}_{\mathrm{oc}}$ of $600 \mathrm{mV}$, FF of 0.49 , and the highest conversion efficiency of $5.17 \%$, in comparison to the imidazolium-based ILs attached with other alkyl chain length, and 2.58 times better than the commercial electrolyte. Thus, the presence of the butyl chain had improved the photovoltaic performance by increasing the charge transport and by hindering the charge recombination. Apart from that, the high values of $\mathrm{V}_{\mathrm{oc}}$ and $\mathrm{J}_{\mathrm{sc}}$ denoted the betterment in ionic conductivity and polarity upon attachment of butyl chain into imidazolium salt moiety.

Other families of heterocyclic were also tested. Sun et al. [34] examined other types of heterocyclic-based IL as a component in the electrolyte of DSSCs. Iodide-based ILs of pyrrolidinium, piperidinium, and morpholinium were synthesized, characterized, and evaluated for their photovoltaic performance. The study sought to identify the relationship between the electrolyte's behaviors and the difference in their structures. For thermal property, all the synthesized ILs showed good thermal stability that ranged from $238-292{ }^{\circ} \mathrm{C}$, thus suggesting their suitability as electrolytes for DSSCs. The study prescribed that the stability was influenced by how symmetrical the cation is. For example, among all, 1-ethyl-1-propylpiperidinium iodide (Pip23) that had the closest symmetrical structure gave the highest value of thermal decomposition, which was at $292^{\circ} \mathrm{C}$. The DSSC electrolyte with pyrrolidinium-based IL, namely 1-butyl-1-methylpyrrolidinium iodide (Pyr14), had shown the highest cell efficiency (6.52\%) owing to the highest diffusion coefficient and the lowest viscosity, when compared to other cyclic ILs.

Tedla and Tai (2018) [35] assessed the stability of DSSCs by using a binary solvent. Unlike most studies, they probed into the stability of the cell after a certain time, instead of focusing solely on cell efficiency. The stability cell test was conducted for 46 days $(11,000 \mathrm{~h})$. The binary solvent was obtained by mixing 1-butyl-3-methylimidazoliumbromide (BMIMBr) with ACN at different ratios; 90:10, 80:20, 70:30, 40:60, and 50:50. Next, the binary solvent was added into the electrolyte mixture that comprised of iodine, LiI, 4-tertbutylpyridine, and 1,2-dimethyl-3-propylimidazolium iodide. As a result, the optimum percentages of the binary solvent to be included in the electrolyte mixture were $10 \%$ and $20 \%$. The cell efficiencies after the addition of $10 \%$ and $20 \%$ binary solvents into the electrolyte mixture were $7.43 \%$ (the highest recorded in the study) and $6.72 \%$, respectively. The difference in cell efficiency between the addition of $10 \%$ binary solvent and without the addition of the binary ILs was 
only $0.01 \%$. Nonetheless, a huge variance was noted for the performance of the cells after 46 days. The cells that contained $10 \%$ and $20 \%$ binary solvents retained $70 \%$ of their initial performances when compared to $60 \%$ retention of performance for the cells without binary solvent. Besides, the cells with $30-50 \%$ of binary ILs were able to retain the initial efficiency at $~ 85 \%$. Despite the high retention value, the overall cell performances were indeed less than that with 10-20\% binary solvent.

Triggered by the instability, toxicity, and cost issues that arise from the use of binary ILs, Fang et al. had synthesized imidazolium-based IL with side alkyl chain that contained double bond [36]. Molecular dynamic simulation suggested that the presence of the double bond can reduce the probability for the ILs to pack, thus resulting in ILs with low viscosity. Thus, 1-(3-hexenyl)-3-methyl imidazolium iodide (HeMII) and 1-(3-butenyl)-3-methyl imidazolium iodide (BeMII) were synthesized, in which their viscosity values were $104 \mathrm{mPa} \cdot \mathrm{s}$ and $80 \mathrm{mPa} \cdot \mathrm{s}$, respectively. Cell efficiencies of $6.85 \%$ and $5.93 \%$ were achieved upon the addition of HeMII and BeMII, respectively, into the electrolyte mixture that contained iodine, LiI, guanidinium thiocyanate, and N-methylbenzimidazole (NMBI). The outcomes were higher when compared to the corresponding saturated structure of 1-hexyl-3-methylimidazolium iodide (HMII), which only yielded $5.17 \%$ cell efficiency. The study suggested enhanced transport properties due to the use of ILs with low viscosity.

The incorporation of different functional groups into cyclic-based ILs had been reported in numerous studies. The physicochemical properties of ILs rely on the degree of interaction between the anion and the cation, as well as between the ionic compounds. This degree of interaction is highly influenced by the presence of the functional groups attached to the based structure. This determines the strength of the formation between the intermolecular interactions, such as hydrogen bonding [37]. Ether-functionalized ILs were reported to have low viscosity when compared to amino, hydroxyl, and carboxyl groups, as well as amide-functionalized ILs, which were prone to hydrogen bonding. The low viscosity of ether-functionalized IL is ascribed to the functional group that resists packing in an orderly manner, thus contributing to more free volume or fluidity.

A study by Zheng et al. [38] investigated the performance of DSSCs by using two ether functionalized cyclic ILs, namely 1-(2-methoxyethyl)-2-ethylpyrazolium bis(trifluoromethylsulfonyl) imide (OEPZTFSI) and 1-(2-methoxyethyl)-2-methylpyrazolium bis(trifluoromethylsulfonyl)imide (OMPZTFSI) as the electrolyte, while pyrazolium iodide as the iodide source. The short-circuit current density $\left(\mathrm{J}_{\mathrm{sc}}\right)$ and the power-conversion efficiency $(\eta)$ were increased as the iodide concentration increased from $0.6 \mathrm{M}$ to $1.0 \mathrm{M}$, but decreased upon further increment. The study prescribed that a too high concentration of iodide increased the probability of recombination and the viscosity, while lowering the ionic conductivity. Upon comparing OEPZTFSI with OMPZTFSI, the former showed better cell efficiency $(1.7 \%)$ as it had lower viscosity than the latter, which was $41.2 \mathrm{mPa} \cdot \mathrm{s}$ at $25^{\circ} \mathrm{C}$.

Song et al. [39] investigated the effect of ILs size on the performance of DSSCs. The study pointed out the significance of optimising the structure of cation (imidazolium) to increase photovoltaic performance. In the study, the size of the cation was systematically increased. The synthesized ILs were 1-cyanoethyl-3-methylimidazolium iodide ([CMI][I]), 1-cyanoethyl-3-butylimidazolium iodide ([CBI][I]), 1-cyanoethyl-3-octylimidazolium iodide ([COI][I]), and 1-cyanoethyl-3-dodecylimidazolium iodide ([CDI][I]) bearing alkyl chains (with cyano group) of one carbon, four carbons, eight carbons, and 12 carbons, respectively. The use of the commercial software, Chem3D Pro 12.00, revealed that the sizes of [CMI][I], [CBI][I], [COI][I], and [CDI][I] were $0.9,0.11,0.16$, and $0.2 \mathrm{~nm}$, respectively. The increase in cation size from [CMI][I] (with methyl chain) to [CBI][I] (with butyl chain) had increased the $\mathrm{J}_{\mathrm{sc}}$, but had slightly decreased the $\mathrm{J}_{\mathrm{sc}}$ when the cation size was further increased to octyl chain [COI][I] and dodecyl chain [CDI][I]. This trend was also similar to cell efficiency, in which the highest cell efficiency $(4.7 \%)$ was obtained with the usage of [CBI][I] (with butyl chain) that gave the highest $\mathrm{J}_{\mathrm{sc}}$ value $\left(10.3 \mathrm{~mA} / \mathrm{cm}^{2}\right)$. As the molecular size increased from one carbon to 12 carbons, both ionic conductivity and diffusion coefficient decreased. The study expected that increment in size could enhance $J_{\mathrm{sc}}$ and $\mathrm{V}_{\mathrm{oc}}$, mainly due to the decrease in electron recombination. However, their expectation was only valid for the case of cations with one and four carbons. The study highlighted the importance 
of the multilayer adsorption of the long alkyl chain on $\mathrm{TiO}_{2}$ that prevented electron recombination and increased the $\mathrm{J}_{\mathrm{sc}}$. The study suggested that the result did not adhere to the expected trend due to the presence of the cyano group, which suppressed the formation of a multilayer adsorption alkyl chain, thus lowering the $\mathrm{TiO}_{2}$ conduction band and increasing the energy barrier that led to slow electron injection.

Dhar et al. [40] studied the effect of different anions on ionic conductivity properties and cell efficiency by combining pyridinium cation with thiocyanate (SCN), bromide (Br), and iodide (I) anions to obtain $2 \mathrm{PrSCN}, 2 \mathrm{PrBr}$, and $2 \mathrm{PrI}$, respectively. Next, the ILs were mixed with PMIMI, $\mathrm{I}_{2}$, TBP, and GSCN in MPN prior to cell efficiency testing. The efficiency of the cells upon the incorporation of $2 \mathrm{PrSCN}, 2 \mathrm{PrBr}$, and $2 \mathrm{PrI}$ into electrolyte formulation were $5.23 \%, 4.61 \%$, and $4.1 \%$, respectively. The highest cell efficiency was noted with the usage of $2 \mathrm{PrSCN}$, which was justified by the ionic conductivity properties. Among the three ILs, $2 \mathrm{PrSCN}$ displayed the highest ionic conductivity value, which was $4.8 \times 10^{-4} \mathrm{~S} \cdot \mathrm{cm}^{-1}$. The thermal stability of the cell with $2 \mathrm{PrSCN}$ was compared to the reference ILs, PMIMI. In the test, $2 \mathrm{PrSCN}$ exhibited better thermal stability as it retained $\sim 96 \%$ of the initial efficiency after being illuminated for $500 \mathrm{~h}$. As a summary, the Table 1 tabulates the compilation of selected ILs used as an electrolyte component in DSSCs with the corresponding composition, cell performance, and stability whenever available. 
Table 1. Ionic liquids incorporated into the electrolyte formulation.

\begin{tabular}{|c|c|c|c|c|c|c|}
\hline Ref. & $\begin{array}{c}\text { Ionic Liquids } \\
\text { (Ionic Conductivity, s; Viscosity, h) }\end{array}$ & $\begin{array}{l}\text { Composition of Electrolyte } \\
\text { (Ionic Conductivity, s) }\end{array}$ & $\mathrm{V}_{\mathrm{oc}}(\mathrm{V})$ & $\mathrm{J}_{\mathrm{sc}}\left(\mathrm{mA} \cdot \mathrm{cm}^{-2}\right)$ & H (\%) & Durability Ref. (\% to the Initial $\eta)$ \\
\hline$[7]$ & $\mathrm{PF}_{6}$ & $\begin{array}{c}{\left[\mathrm{Co}^{2+}\left(\mathrm{phen}_{3}\right]\left(\mathrm{PF}_{6}-\right)_{2} /\left[\mathrm{Co}^{3+}\left(\mathrm{phen}_{3}\right]\left(\mathrm{PF}_{6}{ }^{-}\right)_{3} / \mathrm{Lithium}\right.\right.} \\
\text { perchlorate }(\mathrm{LiClO} 4) / \text { Sodium perchlorate } \\
\left.(\mathrm{NaClO})_{4}\right) / \text { Tetrabutylammonium hexafluorophosphate } \\
(\mathrm{TBAPF}) / \text { Tributylphosphate hexafluorophosphate } \\
\text { (TBPPF)/1-hexyl-3-methylimidazolium hexafluorophosphate } \\
(\mathrm{HMImPF}) / 4 \text {-tert-butylpyridine } \\
\text { (TBP)/4-trimethylsilylpyridine (TMSP)/4-methylpyridine(MP), } \\
\text { 4-cyano-4'-propylbiphenyl (CPrBP), } \\
\text { 4-cyano-4'-pentylbiphenyl (CPeBP), 4-cyano-4'-octylbiphenyl } \\
\text { (COcBP) in MeCN. }\end{array}$ & 1.014 & 18.27 & 14.3 & N.A \\
\hline$[6]$ & -BMII & $\begin{array}{l}\text { 1,3-butylmethylimidazolium iodide }(\mathrm{BMII}) / \mathrm{I}_{2} / \text { guanidinium } \\
\text { thiocyanate/tertbutylpyridine in acetonitrile and valeronitrile }\end{array}$ & - & - & $11-11.3$ & N.A \\
\hline \multirow[t]{3}{*}{ [27] } & & $\begin{array}{l}\text { Dimethylimidazolium iodide } \\
\text { (DMII)/LiI//2/tert-butylpyridine/guanidinium thiocyanate } \\
\text { (GNCS) in acetonitrile and valeronitrile }\end{array}$ & 0.74 & 18.62 & 10.5 & N.A \\
\hline & & $\mathrm{DMII} / \mathrm{I}_{2} / \mathrm{N}$-butylbenzimidazole (NBB)/GNCS in MPN & 0.75 & 17.98 & 9.7 & $97 \%$ after $1000 \mathrm{~h}$ \\
\hline & MII & $\begin{array}{c}\text { 1,3-dimethylimidazoliumiodide } \\
\text { (DMII)/1-ethyl-3-methylimidazolium iodide } \\
\text { (EMII)/1-ethyl-3-methylimidazolium tetracyanoborate } \\
\text { (EMITCB)/I / } / \text {-Butylbenzimidazole (NBB)/guanidinium } \\
\text { thiocyanate (GNCS) }\end{array}$ & 0.68 & 14.77 & 7.41 & $\begin{array}{l}\mathrm{h} \text { changed from } 7.41 \% \text { to } 7.04 \% \text { after } \\
\qquad 1000 \mathrm{~h}\end{array}$ \\
\hline \multirow[t]{2}{*}{ [28] } & VHpII & $\begin{array}{l}\text { 1-vinyl-3-heptylimidazolium iodide } \\
\text { (VHpII)/ } \mathrm{I}_{2} / 4 \text {-terbutylpyridine }\end{array}$ & 0.66 & 6.63 & 2.63 & N.A \\
\hline & & $\begin{array}{l}\text { 1-vinyl-3-heptylimidazolium iodide } \\
\text { (VHpII)// } 2 / 4 \text {-terbutylpyridine/LiI }\end{array}$ & 0.59 & 9.61 & 3.63 & N.A \\
\hline
\end{tabular}


Table 1. Cont.

\begin{tabular}{|c|c|c|c|c|c|c|}
\hline Ref. & $\begin{array}{c}\text { Ionic Liquids } \\
\text { (Ionic Conductivity, s; Viscosity, h) }\end{array}$ & $\begin{array}{l}\text { Composition of Electrolyte } \\
\text { (Ionic Conductivity, s) }\end{array}$ & $\mathrm{V}_{\mathrm{oc}}(\mathrm{V})$ & $\mathrm{J}_{\mathrm{sc}}\left(\mathrm{mA} \cdot \mathrm{cm}^{-2}\right)$ & H (\%) & Durability Ref. (\% to the Initial $\eta$ ) \\
\hline [30] & PMII & $\begin{array}{c}\text { 1-propyl-3-methylimidazolium } \\
\text { (PMII)/1-butyl-3-methylimidazolium thiocyanate } \\
(\text { BMISCN)/I } / \text { LiI }\end{array}$ & 0.62 & 6.52 & 1.89 & N.A \\
\hline [31] & & $\begin{array}{c}\text { 1-ethyl-3-methylimidazolium iodide } \\
\text { (EMII)/1,3-dimethylimidazolium iodide } \\
\text { (DMII)/1-allyl-3-methylimidazolium iodide (AMII)// } 2\end{array}$ & 0.690 & 11.16 & 5.96 & N.A \\
\hline \multirow[t]{5}{*}{ [32] } & & 1,3-diethylimidazolium iodide $(\mathrm{DEII}) / \mathrm{I}_{2}$ in MPN & 0.62 & 12.5 & 4.8 & N.A \\
\hline & & 1-ethyl-3-methylimidazolium iodide (EMII)// $\mathrm{I}_{2}$ in MPN & 0.60 & 12.5 & 4.7 & N.A \\
\hline & & 1-ethyl-3-vinylimidazolium iodide (EVII)/I $\mathrm{I}_{2}$ in MPN & 0.60 & 12.0 & 4.7 & N.A \\
\hline & & $\begin{array}{l}\text { 1-(4-acetophenyl)-3-ethylimidazolium iodide (AcePheEII)/ } \mathrm{I}_{2} \\
\text { in MPN }\end{array}$ & 0.60 & 8.2 & 3.1 & N.A \\
\hline & & 1-hexyl-3-methylimidazolium iodide (HMII)/ $\mathrm{I}_{2}$ in MPN & 0.65 & 11.1 & 4.2 & N.A \\
\hline
\end{tabular}


Table 1. Cont.

\begin{tabular}{|c|c|c|c|c|c|c|}
\hline Ref. & $\begin{array}{c}\text { Ionic Liquids } \\
\text { (Ionic Conductivity, s; Viscosity, h) }\end{array}$ & $\begin{array}{l}\text { Composition of Electrolyte } \\
\text { (Ionic Conductivity, s) }\end{array}$ & $\mathrm{V}_{\mathrm{oc}}(\mathrm{V})$ & $\mathrm{J}_{\mathrm{sc}}\left(\mathrm{mA} \cdot \mathrm{cm}^{-2}\right)$ & H (\%) & Durability Ref. (\% to the Initial $\eta$ ) \\
\hline [33] & (a) & $\begin{array}{l}\text { 3-butyl-1-(1-hydroxy-3-methylbutan-2-yl) imidazolium } \\
\text { iodide (a)/Li/// } \mathrm{I}_{2} \text { in MPN }\end{array}$ & 0.6 & - & 5.17 & N.A \\
\hline [34] & & $\begin{array}{l}\mathrm{LiI} / \mathrm{I}_{2} / 1 \text {-butyl-1-methylpyrrolidinium iodide (Pyr14)/tert-butyl } \\
\text { pyridine (TBP) in acetonitrile (ACN) }\end{array}$ & 0.685 & 14.53 & 6.52 & N.A \\
\hline [35] & & $\begin{array}{l}\text { 1-butyl-3-methylimidazolium bromide (BMIBr)/90\% } \\
\text { ACN// } / \text { /lithium } \\
\text { iodide/4-tertbutylpyridine/1,2-dimethyl-3-propylimidazolium } \\
\text { iodide (DMPII) in ACN }\end{array}$ & 0.8 & 14.27 & 7.43 & $70 \%$ after $11,000 \mathrm{~h}$ \\
\hline [36] & eMII & $\begin{array}{c}\text { 1-(3-hexenyl)-3-methyl imidazolium iodide (HeMII + } \mathrm{I}_{2}+ \\
\text { lithium iodide + guanidinium thiocyanate (GuNCS) }+ \\
\mathrm{N} \text {-methylbenzimidazole (NMBI) }\end{array}$ & 0.725 & 13.52 & 6.85 & N.A \\
\hline [38] & OEPZTFSI & $\begin{array}{l}\text { 1-(2-Methoxyethyl)-2-ethylpyrazolium iodide } \\
\text { (OEPZI)/1-(2-Methoxyethyl)-2-ethylpyrazolium } \\
\text { bis(trifluoromethylsulfonyl)imide (OEPZTFSI)/I } 2\end{array}$ & 0.55 & 6.3 & 1.7 & N.A \\
\hline & OEPZI & & & & & \\
\hline
\end{tabular}


Table 1. Cont.

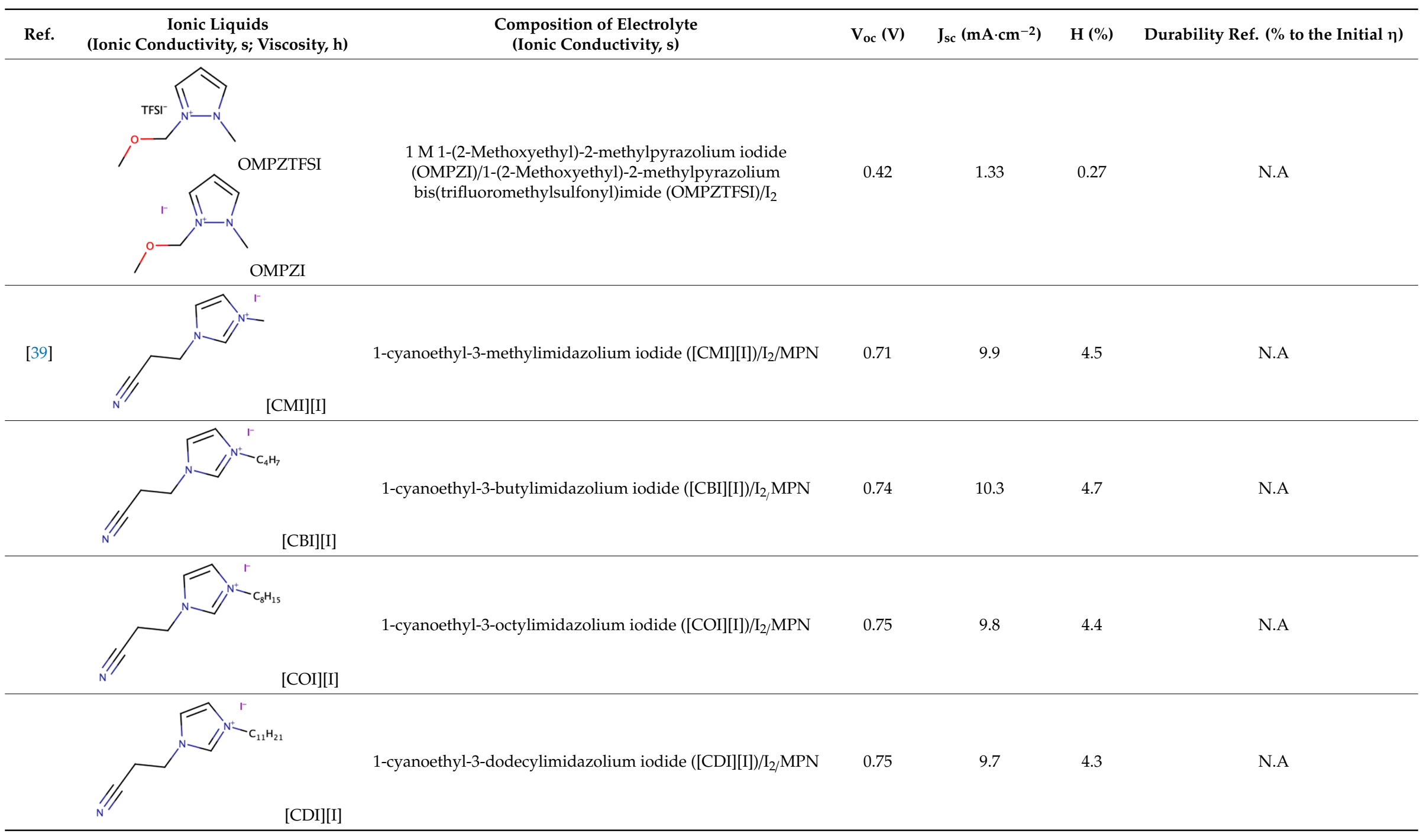


Table 1. Cont.

\begin{tabular}{|c|c|c|c|c|c|c|}
\hline Ref. & $\begin{array}{c}\text { Ionic Liquids } \\
\text { (Ionic Conductivity, s; Viscosity, h) }\end{array}$ & $\begin{array}{l}\text { Composition of Electrolyte } \\
\text { (Ionic Conductivity, s) }\end{array}$ & $\mathrm{V}_{\mathrm{oc}}(\mathrm{V})$ & $\mathrm{J}_{\mathrm{sc}}\left(\mathrm{mA} \cdot \mathrm{cm}^{-2}\right)$ & $\mathrm{H}(\%)$ & Durability Ref. (\% to the Initial $\eta$ ) \\
\hline [40] & & $\begin{array}{l}\text { pyridinium-clubbed dicationic ionic liquid with SCN anion } \\
(2 \mathrm{PrSCN}) / \mathrm{PMII} / \mathrm{I}_{2} / \mathrm{TBP} / \mathrm{GSCN} \text { in MPN }\end{array}$ & 0.728 & 10.08 & 5.23 & $96 \%$ after $500 \mathrm{~h}$ \\
\hline [41] & & $\begin{array}{c}\text { PEO (polyethylene carbonate)/DMPII } \\
\text { (1,2-dimethyl-3-propylimidazolium iodide)/ACN/KI }\end{array}$ & 0.68 & 15 & $5.7 \%$ & N.A \\
\hline \multirow[t]{4}{*}{ [42] } & - & $\begin{array}{c}\text { Poly(ethylene oxide) [sodium iodide }+ \text { Ethylene carbonate }+ \\
\text { propylene }] / I_{2}\end{array}$ & 0.534 & 18.77 & 6.62 & N.A \\
\hline & PMII & $\begin{array}{l}\text { Poly(ethylene oxide) [sodium iodide }+ \text { ethylene carbonate }+ \\
\text { propylene carbonate }+1 \text {-methyl-3-propylimidazolium iodide } \\
(\mathrm{PMII})] / \mathrm{I}_{2} \mathrm{~s}: 9.41 \mathrm{mS} \cdot \mathrm{cm}^{-1}\end{array}$ & 0.559 & 24.55 & 9.35 & N.A \\
\hline & 3MII & $\begin{array}{l}\text { Poly(ethylene oxide) [sodium iodide }+ \text { ethylene carbonate }+ \\
\text { propylene carbonate }+1 \text {-butyl-3-methylimidozium iodide } \\
(\mathrm{BMII})] / \mathrm{I}_{2} \mathrm{~s}: 8.48 \mathrm{mS} \cdot \mathrm{cm}^{-1}\end{array}$ & 0.569 & 18.82 & 7.28 & N.A \\
\hline & HMII & $\begin{array}{l}\text { Poly(ethylene oxide)[sodium iodide+ ethylene carbonate }+ \\
\text { propylene carbonate }+1 \text {-hexyl-3-methylimidozium iodide } \\
\qquad(\mathrm{HMII}) / \mathrm{I}_{2} \text { s: } 7.73 \mathrm{mS} \cdot \mathrm{cm}^{-1}\end{array}$ & 0.564 & 20.80 & 7.87 & N.A \\
\hline [43] & MII & $\begin{array}{c}\text { poly(acrylic acid/gelatin) } \\
\text { [poly(AA/GR)]//2/LiI/PMII/AMIMBF4/N-methyl pyrrolidone. } \\
\text { s: } 18.44 \mathrm{mS} \cdot \mathrm{cm}^{-1}\end{array}$ & 0.73 & 14.27 & 7.15 & N.A \\
\hline [44] & $\begin{array}{l}\mathrm{C} 11 \mathrm{MImI} \\
\text { h: } 230 \mathrm{mPa} \cdot \mathrm{s}\left(40^{\circ} \mathrm{C}\right)\end{array}$ & 1-undecyl-3-methylimidazolium iodide (C11MImI)/ $\mathrm{I}_{2}$ & - & 6.0 & - & N.A \\
\hline
\end{tabular}


Table 1. Cont.

\begin{tabular}{|c|c|c|c|c|c|c|}
\hline Ref. & $\begin{array}{c}\text { Ionic Liquids } \\
\text { (Ionic Conductivity, s; Viscosity, h) }\end{array}$ & $\begin{array}{l}\text { Composition of Electrolyte } \\
\text { (Ionic Conductivity, s) }\end{array}$ & $\mathrm{V}_{\mathrm{oc}}(\mathrm{V})$ & $\mathrm{J}_{\mathrm{sc}}\left(\mathrm{mA} \cdot \mathrm{cm}^{-2}\right)$ & H (\%) & Durability Ref. (\% to the Initial $\eta$ ) \\
\hline & & 1-undecyl-3-methylimidazolium iodide (C11MImI)/ $\mathrm{I}_{2} /$ gelator & - & 6.0 & - & N.A \\
\hline & & 1-dodecyl-3-methylimidazolium iodide (C12MImI)// 2 & - & 7.0 & - & N.A \\
\hline & & 1-dodecyl-3-methylimidazolium iodide $(\mathrm{C} 12 \mathrm{MImI}) / \mathrm{I}_{2} /$ gelator & - & 7.7 & - & N.A \\
\hline [45] & & 1-dodecyl-3-ethylimidazolium iodide (C12EImI)/ $\mathrm{I}_{2}$ & 0.7 & 7.5 & 2.57 & N.A \\
\hline [46] & & $\begin{array}{l}\text { Succinonitrile/dimethyl propylimidazolium iodide (DMPII)/I } \\
\text { s: } 3.7 \mathrm{mS} \cdot \mathrm{cm}^{-1}\end{array}$ & 0.808 & 12.67 & 7.2 & N.A \\
\hline [47] & & $\begin{array}{l}\text { poly-1-[(4-ethenylphenyl)methyl]-3-butylimidazolium iodide } \\
\text { (PEBII)/1-propyl-3-methyl imidazolium iodide (PMII) }\end{array}$ & 0.63 & 17 & 5.83 & N.A \\
\hline
\end{tabular}




\section{Ionic Liquids in Solid or Quasi-Solid Electrolyte for DSSCs}

In a countless number of studies, the addition of ILs into organic solvent-based electrolyte was often claimed to solve its instability that could easily vaporize, especially in elevated temperature or long-term condition. Over time, the organic solvent will evaporate and cause deterioration of the solar cells. This has become the main reason for introducing polymer-based electrolyte. The polymer-based electrolytes can be further classified into solid and gel polymer electrolytes (GPEs). These two can be differentiated based on their physical attributes, in which the solid polymer electrolyte has a solid physical characteristic, while GPE is between solid and liquid (gel-like properties). This consistency classically can be achieved by using certain preparation methods, such as heat-induced or UV-cured or simply by adding certain materials, such as plasticizer, into the mixture of polymer host with the electrolyte components [48].

Polymer electrolytes in both solid and gel states have very low ionic conductivity [49]. The presence of salt, such as LiI and KI, together with the polymer host material, is integral to provide the necessary ionicity to the polymer electrolyte. Upon the discovery of $\mathrm{IL}$, it has gained popularity to be incorporated into the polymer electrolyte, to enhance the ionicity and the overall performance of the photovoltaic cell [49]. Due to this, ILs had been substantially mixed into the polymer host to improve the transport properties of these materials towards achieving high cell efficiency. Often, the effect that takes place due to the improvements of the electrolyte properties can be observed on the cell performance parameters, such as $\mathrm{J}_{\mathrm{sc}}, \mathrm{V}_{\mathrm{oc}}$, and FF. These parameters have been discussed in the previous section of this review.

Polyethylene oxide (PEO) a commonly used polymer in electrolyte studies, which is semi-crystalline, impedes the electron movement and decreases the ionic conductivity. The addition of imidazolium-based IL into GPE was intended to overcome this disadvantage. The presence of ILs in PEO was intended as a plasticizer to decrease the crystallinity and simultaneously increase the probability for the electrolyte to infiltrate into the $\mathrm{TiO}_{2}$ layer. This is beneficial in terms of ionic conductivity. Chen et al. [41] assessed the free iodine GPE for DSSCs by mixing the PEO with potassium iodide (KI), IL (1,3-dimethylpropylimidazolium iodide (DMPII)), and ACN. Since there was no iodine in the electrolyte, the study sought the optimum percentage of salt (KI), which was the source of iodide that had reacted with oxidized dye to obtain triiodide species. As a result, the optimum concentration of salt KI added into electrolyte was 5\%, in which the cell efficiency obtained was 5.87\%. Excessive $\mathrm{KI}$ at $7 \%$ led to slightly lower cell efficiency (5.72\%). It is important to note that, for a polymer-based electrolyte, increasing the amorphous structure of the polymer host is a vital factor as it can ease the hopping of ions and enhance conductivity.

Using the same polymer, Syairah et al. [42] evaluated the incorporation of imidazolium-based ILs of different alkyl chain lengths into PEO with ethylene carbonate (EC) and propylene carbonate (PC) as solvents. Ionic liquids (ILs), namely 1-methyl-3-propylimidazolium iodide (PMII), 1-butyl-3-methylimidazolium (BMII), and 1-hexyl-3-methylimidazolium iodide (HMII), were used as an additive in the GPE. In the study, PMII, BMII, and HMII were mixed with PEO to form the gel polymers denoted as S1, S2, and S3, respectively. The study was focused on establishing a connection between the use of imidazolium-based ILs of different alkyl chain lengths and the resulting ionic conductivities of the GPEs and the DSSCs power conversion efficiencies. As a result, the addition of ILs into the GPEs had increased the ionic conductivity, whereby the presence of the lone pair electron in the conjugated system of imidazolium-based IL had facilitated the flow of ions. The highest conductivity was shown for S1 at $9.41 \mathrm{mS} \cdot \mathrm{cm}^{-1}$, which also led to the highest conversion efficiency at $9.35 \%$, in comparison to S2, S3, and SB (GPE without IL). From the current versus voltage (I-V) data of the solar cells, it was revealed that the addition of ILs had increased the $\mathrm{V}_{\mathrm{oc}}$. Furthermore, the usage of low viscosity ILs had improved the transport properties of the electrolyte, as S1 possessed the lowest viscosity.

$\mathrm{Li}$ et al. [43] reported the imbibition of ILs into the polymer host poly(acrylic acid/gelatin) [poly(AA/GR)], and poly(acrylic acid/cetyltrimethylammonium ammonium bromide) [poly(AA/CTAB)] matrices to increase ionic conductivity, cell efficiency, and stability. The study compared the efficiency 
and the stability of the cells that used ILs imbibed polymer-based electrolyte with ACN imbibed polymer-based electrolyte. Their primary concern was on the nature of the organic solvent, ACN, which easily vaporized when incorporated in a GPE. For the preparation of the IL electrolyte, $0.5 \mathrm{M} \mathrm{I}_{2}$ and $0.01 \mathrm{M}$ LiI were added into 40 volume \% PMII, 50 volume \% [AMIM]BF4, and 10 volume \% $\mathrm{N}$-methyl pyrrolidone. The GPEs were prepared by immersing $0.2 \mathrm{~g}$ of [poly (AA/GR)] or [poly (AA/CTAB)] into the IL electrolyte formulation. The same procedure was conducted to obtain the ACN-contained iodide imbibed poly (AA/GR) and the $\mathrm{ACN}$-contained iodide imbibed poly (AA/CTAB), except that the ACN was used as a solvent in the electrolyte formulation. The ionic conductivity of ILs imbibed [poly(AA/GR)], ILs imbibed [poly(AA/CTAB)], ACN-contained iodide imbibed poly(AA/GR), and ACN-contained iodide imbibed poly(AA/CTAB) were $15.36,12.95,13.84$, and $10.73 \mathrm{mS} \cdot \mathrm{cm}^{-1}$, respectively. The cell that had incorporated ILs imbibed [poly (AA/GR)] as electrolyte showed the highest cell efficiency of $7.19 \%$. This value was comparable to the efficiency recorded when the cell employed IL electrolyte alone (without polymer matrix), which was at $7.27 \%$. As for the stability test, the data showed that the DSSCs with ILs imbibed [poly(AA/GR)] and poly(AA/CTAB) retained $97 \%$ of their initial efficiencies, which were better than those with $A C N$-contained iodide imbibed [poly(AA/GR)] and poly(AA/CTAB), which only managed to retain $83 \%$ of their initial efficiencies.

The transport mechanism in an electrolyte is principally through conventional or physical diffusion. The viscosity of the electrolyte is a key factor in determining the efficiency of ion transport. This is true for the case of liquid electrolyte, in which the use of ILs with low viscosity is favored as they promote physical diffusion that increases ionic conductivity. Another transport mechanism refers to transfer diffusion or electron exchange [50-52], which occurs due to effective collision during physical diffusion. This mechanism is significant mainly in the case of the usage of very high viscosity or solid ILs, wherein physical diffusion is not favorable. In a study by Yamanaka et al. [44], a very ordered structure of highly viscous ILs had positively affected $\mathrm{J}_{\mathrm{sc}}$. It was observed that the use of imidazolium-based ILs with alkyl chain of 12 carbons formed an ordered smectic A phase, which gave better $\mathrm{J}_{\mathrm{sc}}$, when compared to one without smectic A phase (imidazolium-based ILs with alkyl chain of 11 carbons (C11MImI)). In smectic A phase, the ions are well aligned, and this helps to ease the electron exchange to occur. Although the viscosity of C12MImI was high due to the 12-carbon alkyl chain, the nature of C12MImI in ordered smectic A phase eases electron hopping and increases conductivity, when compared to C11MImI with lower viscosity. The addition of gelator to C12MImI with iodine in the electrolyte had increased the $\mathrm{J}_{\mathrm{sc}}$ value from 7.0 to $7.7 \mathrm{~mA} \cdot \mathrm{cm}^{-2}$. The increment in $\mathrm{J}_{\mathrm{sc}}$ is attributed to the organization of the structure.

The study had inspired Pan et al. in 2013 [45] to use ILs with smectic A phase to be incorporated as electrolyte for DSSCs. Thus, ILs with long alkyl chain, 1-dodecyl-3-ethylimidazolium iodide (C12EImI) that physically exists as solid and 1-decyl-3-ethylimidazolium iodide (C10EImI) that exists as a thick liquid, were chosen to be combined with iodine to serve as electrolytes for DSSCs. The cell that employed C12EImI achieved $2.57 \%$ power conversion efficiency, which was greater than that of C10EImI. The diffusion coefficient of triiodide in C12EImI was greater than C10EImI due to the presence of the smectic A phase. This phase promotes exchange reaction $\left(D_{e x}\right)$, which is beneficial to the transport properties of polyionic liquid that is in solid form. As C10EImI existed physically as a liquid, this study signifies that the physical characteristics of the electrolyte are not the only factor that determines the cell efficiency.

The ss-polymer electrolyte is attractive due to its mechanical strength. This quality makes DSSC manufacturable. However, it has low ionic conductivity that causes low cell efficiency. The addition of salt is crucial to increase ionicity. Thus, Lee et al., [53] compared the use of different salts towards the parameters that contributed to cell efficiency. Among the salts were LiI, sodium iodide (NaI), ammonium iodide $\left(\mathrm{NH}_{4} \mathrm{I}\right)$, and IL (1-propyl-3-methylimidazolium iodide (PMII)). In the study, polyphosphazenes was combined with iodine and different salts to make up the electrolyte component of DSSCs. The best cell efficiency was recorded at $1.88 \%$ using PMII, thus proving the ability of IL as an ionicity provider. The study reported that the increment of iodine into the electrolyte exerted a positive effect on the 
ionic conductivity, while concurrently decreasing the $\mathrm{J}_{\mathrm{sc}}$ and lowering the cell efficiency. This was due to the increase in recombination or dark current.

According to Hwang et al. [46], the doping of ILs and iodine into an organic plastic crystal (succinonitrile (SN)) had increased the ionic conductivity of the material from $10^{-8}-10^{-6} \mathrm{~S} \cdot \mathrm{cm}^{-1}$ to $10^{-3} \mathrm{~S} \cdot \mathrm{cm}^{-1}$. The ionic conductivity after adding ILs into SN was $3.7 \mathrm{mS} \cdot \mathrm{cm}^{-1}$. In the study, branched solid ILs namely 1-alkyl-2,3-dimethylimidazolium iodides with a variety of alkyl chain lengths, were purposely used to form solid state electrolytes. In the first place, the commonly used iodide-based IL, alkyl-methylimidazolium iodide (AMIM)-based ILs with varying alkyl chain lengths, were used. However, due to the liquid nature of the AMIM used, only a small percentage could be doped into the SN polymer matrices, while concurrently retaining the solid final product. Hence, ILs with extra methyl group, 1-alkyl-2,3-dimethylimidazolium iodides, were employed to ensure that the end product remained as solid. The highest cell efficiency was $7.2 \%$, which was achieved by using 1-propyl-2,3-dimethylimidazolium iodide (DMPII)-doped SN as the electrolyte.

In a study by Chi et al. [47], an IL that contained phenyl substituent moiety with a single aliphatic $\mathrm{C}=\mathrm{C}$ bond, 1-[(4-ethenylphenyl)methyl]-3-butyl-imidazolium iodide (EBII), was served as a monomer to form polymer electrolyte, poly-1-[(4-ethenylphenyl)methyl]-3-butyl-imidazolium iodide (PEBII). The incorporation of phenyl group resulted in a $\pi-\pi$ stacking that increased the polymer conductivity, and consequently, the cell efficiency. The conversion efficiency of DSSCs that employed PEBII was $5.93 \%$. The study further experimented with the addition of viscous IL, 1-propyl-3-methyl imidazolium iodide (PMII) as part of the polymer electrolyte. However, this inclusion had reduced cell efficiency to $5.83 \%$. In this case, the presence of PMII had increased the rate of electron recombination.

In the works included as part of this review, the incorporation of ILs into the electrolyte formulation had affected, in particular, the transport properties of the electrolyte, such as viscosity, ionic conductivity, and diffusion coefficient $[27,29-31,36,38]$. The combination of a variety of cations with anions, the introduction of certain functional groups into the moiety of cations, or the addition of one or more high fluidity ILs into another IL were intended specifically to improve these properties [27,29-31,36,38,45-49]. As discussed in Section 2, the two essential parameters that determine the cell efficiency are $\mathrm{J}_{\mathrm{sc}}$ and $\mathrm{V}_{\mathrm{oc}}$. These parameters were correlated with how well the processes involving the transport of electrons occur, such as the electron injection at the interface of $\mathrm{TiO}_{2} /$ electrolyte, the regeneration process of the oxidized dye, and the shielding of the electron recombination [21,22]. The use of an organic solvent, which is less viscous, renders the electron injection at the interface of $\mathrm{TiO}_{2} /$ electrolyte and the regeneration of oxidized dye to take place efficiently, thus resulting in high cell efficiency. The use of organic solvent enables to solvate the redox couple, hence causing the diffusion coefficient of triiodide to be high, easing the regeneration of oxidized dye [15] and reducing the possibility of recombination from occurring.

The use of viscous ILs, nonetheless, displayed a different effect on these parameters. A viscous solvent environment reduces the mass transport of the ions in the electrolyte. The diffusion coefficient of the redox couple was lowered by 10-100 times in the presence of ILs as a solvent, when compared to that using organic solvent $[13,25]$. Slow regeneration of oxidized dye makes it susceptible to recombine with an injected electron at $\mathrm{TiO}_{2}$ [29]. Due to this, high ions diffusion of the redox couple is desirable. Although some had suggested that the presence of bulky cation from ILs can help in reducing the recombination process, but the improvement of $\mathrm{V}_{\mathrm{oc}}$ was rather mediocre and could not drastically boost up the cell efficiency $[23,24]$. As a result, up until now, the DSSCs performances that used organic solvents in the electrolyte remain unbeatable. Hence, significant efforts were still made to decrease the viscosity $[25,27-29,35,37]$ of the ILs-based electrolytes and to improve the ionic conductivity $[25,27-29,34,36,42,45,48,49,52,53]$, hence increasing the cell efficiency.

\section{Challenges and Future Directions}

The primary aim of incorporating ILs into the formulation of the electrolyte of DSSCs is to improve the thermal stability of DSSCs, especially for liquid-based electrolytes [6,7,25-52]. This thermal 
instability issue originates from the use of easily vaporized organic solvent. Based on the results reported, ILs did exhibit the ability to address this problem. This is justified by the high percentage of retainment of initial efficiency of DSSCs after prolonged exposure to light illumination for a certain period $[27,35,40]$.

Despite this positive outcome from the usage of ILs, one major drawback refers to the fact that organic solvent is still used as an important element of the electrolyte. In the first place, the idea behind using ILs was to take over the role of organic solvent as the solvent component in the electrolyte. As noted, only a small fraction of the studies had focused on the long-term stability of the cell. Moreover, most studies on DSSCs emphasized more on getting the highest cell efficiency, while omitting the long-term cell stability as a priority. For example, the best cell efficiency reported to date is $14.3 \%$ under standard test condition, which was achieved by using acetonitrile as the solvent in the electrolyte.

To realize the commercialization of DSSC, it is vital to eliminate the organic solvent as a component in the electrolyte. However, the use of only IL in the electrolyte as the solvent shows a decrease in power conversion efficiency, when compared to that using organic solvent [54]. Therefore, a compromise between cell performance efficiency and long-term stability has to be weighed in.

The addition of ILs in the development of polymer electrolytes quasi-systematically to improve the ionicity of the polymer has been largely accepted. On another note, the cell efficiency achieved by gel polymers, although promising, appeared to be lower than that using liquid electrolyte [49]. The highest cell efficiency recorded for polymer electrolyte DSSC was $\sim 10 \%$.

Based on the discussion presented in this review, the inclusion of ILs into liquid and polymer (solid and gel) electrolytes is to serve as additive and source of ionicity, respectively. Regardless of how ILs are considered or called in every study reported, their role is still similar-to improve the transport property, namely ionic conductivity. On that account, the misconception on the function of ILs needs to be clarified, as ILs at present may not act as an efficient solvent to replace organic solvent, wherein direct comparison with the latter will rather jeopardize the advantage of ILs, as discussed in this review. The usage of imidazolium-based ILs is prevalent across all applications, not only limited to DSSCs. This is ascribed to the establishment of their remarkable performance upon incorporation into the electrolyte of DSSCs for more than two decades.

Further efforts need to be made to explore other cations and anions, as different combinations of cation and anion may provide different physical and chemical properties. This can be performed with the help of the existing predictive modelling that will save time and cost [55] in designing and selecting potential ILs for the desired needs. Another way to completely eradicate the problems that revolve around the use of liquid-based electrolyte is to use a solid-state electrolyte. The 2,2,7,7-tetrakis [N, N-bis(p-methoxyphenyl) amino]-9,9-spirobi-fluorene (spiro-OMeTAD) is considered as the hole transporting material of choice for ss-DSSC. The advantage of this material is that the HOMO level of spiro-OMeTAD is of a good match to the fermi level of the conducting band of the semiconductor (namely $\mathrm{TiO}_{2}$ ), thus enabling an optimal hole transfer. Nevertheless, the addition of a hygroscopic LiTFSI salt in the system to improve the conductivity of spiro-OMeTAD can cause the HTM to degrade, thus deteriorating cell efficiency [56]. This prevents from achieving long term and durable ss-DSSCs. Hence, another area that may be considered is the incorporation of thermally stable and non-hygroscopic ILs into the HTM to form a stable solid-state electrolyte with a high cell efficiency, mainly because the ILs are an excellent ionicity provider.

\section{Conclusions}

A variety of ILs have been used in DSSCs electrolyte. Among them, ILs based on imidazolium cation and iodide anion are preferred. The former is due to the low viscosity of the resulting ILs, whereas the latter serves as one of the redox couples, crucial for the dye regeneration. Other types of cations (e.g., pyridinium, pyrazolium, and pyrrolidinium) and anions (e.g., tetracyanoborate, thiocyanate, bromide, and bis(trifluoromethylsulfonyl)imide) have been reported as well. Most studies that had assessed liquid or polymer type electrolytes emphasized the incorporation of certain functional 
group(s) to offer desirable properties, such as low viscosity and high ionic conductivity. Improved transport properties are critical, as the ILs are meant to solve the problems that arise due to the usage of organic solvent. Although acetonitrile and other nitrile-based solvents have excellent transport properties, they exhibit poor thermal stability. However, the total elimination of organic solvents from DSSCs electrolyte resulted mostly in lower cell conversion efficiency. Nevertheless, it is to highlight that the utilization of ILs as an excellent ionicity provider is relevant towards providing long term stability and sustainable energy devices.

Author Contributions: R.A.A.T. initially drafted the review article. W.Z.N.Y. and M.A.B. were involved in planning and supervising the work, revising critically for important intellectual content, providing critical feedback, and helping shape the analysis of the review manuscript. All authors have read and agreed to the published version of the manuscript.

Funding: This research work was funded by Yayasan Universiti Teknologi Petronas (YUTP-FRG), grant number 015LCO-080.

Acknowledgments: The authors would like to acknowledge the Chemical Engineering Department and Centre of Ionic Liquid (CORIL) of Universiti Teknologi PETRONAS for the technical support and financial support by the funder.

Conflicts of Interest: The authors declare no conflict of interest.

\section{References}

1. Mozaffari, S.; Nateghi, M.R.; Zarandi, M.B. An overview of the Challenges in the commercialization of dye sensitized solar cells. Renew. Sustain. Energy Rev. 2017, 71, 675-686. [CrossRef]

2. Sustainable Development Goals. Available online: https://sustainabledevelopment.un.org/sdgs (accessed on 30 June 2020).

3. Parida, B.; Iniyan, S.; Goic, R. A review of solar photovoltaic technologies. Renew. Sustain. Energy Rev. 2011, 153, 1625-1636. [CrossRef]

4. O'Regan, B.; Grätzel, M. A low-cost, high-efficiency solar cell based on dye-sensitized colloidal TiO 2 films. Nature 1991, 353, 737-740. [CrossRef]

5. Nazeeruddin, M.K.; Péchy, P.; Renouard, T.; Zakeeruddin, S.M.; Humphry-Baker, R.; Comte, P.; Liska, P.; Cevey, L.; Costa, E.; Shklover, V.; et al. Engineering of Efficient Panchromatic Sensitizers for Nanocrystalline $\mathrm{TiO}_{2}$-Based Solar Cells. J. Am. Chem. Soc. 2001, 123, 1613-1624. [CrossRef] [PubMed]

6. Nazeeruddin, M.K.; De Angelis, F.; Fantacci, S.; Selloni, A.; Viscardi, G.; Liska, P.; Grätzel, M. Combined Experimental and DFT-TDDFT Computational Study of Photoelectrochemical Cell Ruthenium Sensitizers. J. Am. Chem. Soc. 2005, 127, 16835-16847. [CrossRef]

7. Kakiage, K.; Aoyama, Y.; Yano, T.; Oya, K.; Fujisawa, J.I.; Hanaya, M. Highly-efficient dye-sensitized solar cells with collaborative sensitization by silyl-anchor and carboxy-anchor dyes. Chem. Commun. 2015, 51, 15894-15897. [CrossRef] [PubMed]

8. Cao, Y.; Saygili, Y.; Ummadisingu, A.; Teuscher, J.; Luo, J.; Pellet, N.; Giordano, F.; Zakeeruddin, S.M.; Moser, J.; Freitag, M.; et al. 11\% efficiency solid-state dye-sensitized solar cells with copper (II/I) hole transport materials. Nat. Commun. 2017, 8, 15390. [CrossRef] [PubMed]

9. Wu, J.; Lan, Z.; Lin, J.; Huang, M.; Huang, Y.; Fan, L.; Luo, G. Electrolytes in Dye-Sensitized Solar Cells. Chem. Rev. 2015, 115, 2136-2173. [CrossRef]

10. Harikisun, R.; Desilvestro, H. Long-term stability of dye solar cells. Sol. Energy 2011, 85, 1179-1188. [CrossRef]

11. Eftekhari, A.; Yang, L.; Chen, P. Different roles of ionic liquids in lithium batteries. J. Power Sources 2016, 334, 221-239. [CrossRef]

12. Ahosseini, A.; Scurto, A.M. Viscosity of Imidazolium-Based Ionic Liquids at Elevated Pressures: Cation and Anion Effects. Int. J. Thermophys. 2008, 29, 1222-1243. [CrossRef]

13. Murugesan, S.; Quintero, O.A.; Chou, B.P.; Xiao, P.; Park, K.; Hall, J.W.; Jones, R.A.; Henkelman, G.; Goodenough, J.B.; Stevenson, K.J. Wide electrochemical window ionic salt for use in electropositive metal electrodeposition and solid state Li-ion batteries. J. Mater. Chem. A 2014, 2, 2194-2201. [CrossRef]

14. Gorlov, M.; Kloo, L. Ionic liquid electrolytes for dye-sensitized solar cells. Dalton Trans. 2008, 20, $2655-2666$. [CrossRef] [PubMed] 
15. Iftikhar, H.; Sonai, G.G.; Hashmi, S.G.; Nogueira, A.F.; Lund, P.D. Progress on Electrolytes Development in Dye-Sensitized Solar Cells. Materials 2019, 12, 1998. [CrossRef]

16. Lee, C.; Ho, K. Poly(ionic liquid)s for dye-sensitized solar cells: A mini-review. Eur. Polym. J. 2018, 108, 420-428. [CrossRef]

17. Mahmood, A. Recent research progress on quasi-solid-state electrolytes for dye-sensitized solar cells. J. Energy Chem. 2015, 24, 686-692. [CrossRef]

18. Yusuf, S.N.F.; Yahya, R.; Arof, A.K. Ionic Liquid Enhancement of Polymer Electrolyte Conductivity and their Effects on the Performance of Electrochemical Devices. In Progress and Developments in Ionic Liquids; Handy, S., Ed.; IntechOpen: London, UK, 2017; pp. 157-183. [CrossRef]

19. Mohamad, A.A. Physical properties of quasi-solid-state polymer electrolytes for dye-sensitised solar cells: A characterisation review. Sol. Energy 2019, 190, 434-452. [CrossRef]

20. Kushwaha, R.; Srivastava, P.; Bahadur, L. Natural pigments from plants used as sensitizers for $\mathrm{TiO}_{2}$ based dye-sensitized solar cells. J. Energy 2013, 2013, 1-8. [CrossRef]

21. Carella, A.; Borbone, F.; Centore, R. Research Progress on Photosensitizers for DSSC. Front. Chem. 2018, 6, 481. [CrossRef]

22. Grätzel, M. Dye-sensitized solar cells. J. Photochem. Photobiol. C 2003, 4, 145-153. [CrossRef]

23. Lee, C.; Chen, P.; Ho, K. Ionic Liquid Based Electrolytes for Dye-Sensitized Solar Cells. In Ionic Liquids: Theory, Properties, New Approaches; Kakarin, A., Ed.; IntechOpen: London, UK, 2011; pp. 631-657. [CrossRef]

24. Li, C.; Chang, L.; Fan, M.; Chen, P.; Lin, J.J.; Ho, K.C.; Lee, C. New Class of Ionic Liquids for Dye-Sensitized Solar Cells. In Ionic Liquids: Current State of Art; Scott, H., Ed.; IntechOpen: London, UK, 2015; pp. 655-677. [CrossRef]

25. Hao, F.; Lin, H.; Zhang, J.; Zhuang, D.; Liu, Y.; Li, J. Influence of iodine concentration on the photoelectrochemical performance of dye-sensitized solar cells containing non-volatile electrolyte. Electrochim. Acta 2010, 55, 7225-7229. [CrossRef]

26. Listorti, A.; Regan, B.O.; Durrant, J.R. Electron Transfer Dynamics in Dye-Sensitized Solar Cells. Chem. Mater. 2011, 23, 3381-3399. [CrossRef]

27. Gao, F.; Wang, Y.; Shi, D.; Zhang, J.; Wang, M.; Jing, X.; Humprey-Baker, R.; Wang, P.; Zakeeruddin, S.M. Enhance the Optical Absorptivity of Nanocrystalline $\mathrm{TiO}_{2}$ Film with High Molar Extinction Coefficient Ruthenium Sensitizers for High Performance Dye-Sensitized Solar Cells. J. Am. Chem. Soc. 2008, 130, 10720-10728. [CrossRef] [PubMed]

28. Kang, M.G.; Ryu, K.S.; Chang, S.H.; Park, N.G. A new ionic liquid for a redox electrolyte of dye-sensitized solar cells. ETRI J. 2004, 26, 647-652. [CrossRef]

29. Papageorgiou, N.; Athanassov, Y.; Armand, P.; Bonhote, H.; Azam, A.; Grätzel, M. The Performance and Stability of Ambient Temperature Molten Salts for Solar Cell Applications. J. Electrochem. Soc. 1996, 143, 3099. [CrossRef]

30. Yusof, S.M.M.; Yahya, W.Z.N. Binary Ionic Liquid Electrolyte for Dye-Sensitized Solar Cells. Procedia Eng. 2016, 148, 100-105. [CrossRef]

31. Cao, Y.; Zhang, J.; Bai, Y.; Li, R.; Zakeeruddin, S.M.; Grätzel, M.; Wang, P. Dye-sensitized solar cells with solvent-free ionic liquid electrolytes. J. Phys. Chem. C 2008, 112, 13775-13781. [CrossRef]

32. Son, M.S.; Kang, M.G.; Vittal, R.; Lee, J.; Kim, K.J. Effects of substituents of imidazolium cations on the performance of dye- sensitized $\mathrm{TiO}_{2}$ solar cells. J. Appl. Electrochem. 2008, 38, 647-1652. [CrossRef]

33. Denizalti, S.; Ali, A.K.; Ela, Ç.; Ekmekci, M.; Erten-Ela, S. Dye-sensitized solar cells using ionic liquids as redox mediator. Chem. Phys. Lett. 2018, 691, 373-378. [CrossRef]

34. Sun, I.W.; Wang, H.P.; Teng, H.; Su, S.G.; Lin, Y.C.; Kuo, C.W.; Wu, T.Y. Cyclic ammonium-based ionic liquids as potential electrolytes for dye-sensitized solar cells. Int. J. Electrochem. Sci. 2012, 7, 9765-9780.

35. Tedla, A.; Tai, Y. Influence of Binary Solvent System on the Stability and Efficiency of Liquid Dye Sensitized Solar Cells. J. Photochem. Photobiol. A 2018, 358, 70-75. [CrossRef]

36. Fang, Y.; Ma, P.; Cheng, H.; Tan, G.; Wu, J.; Zheng, J.; Fang, S.; Dai, Y.; Lin, Y. Synthesis of Low-Viscosity Ionic Liquids for Application in Dye-Sensitized Solar Cells. Chem. Asian J. 2019, 14, 4201-4206. [CrossRef] [PubMed]

37. Ohno, H.; Fukumoto, K. Progress in Ionic Liquids for Electrochemical Reaction Matrices. Electrochemistry 2008, 76, 16-23. [CrossRef] 
38. Zheng, Y.; Huang, Q.; Fang, S.; Yang, L.; Gan, Y. Ether-Functionalized Pyrazolium Ionic Liquids as Electrolytes for Dye Sensitized Solar Cells. Int. J. Electrochem. Sci. 2013, 8, 9558-9567.

39. Song, D.; Choi, Y.; Su, B.; Sik, H.; Soo, Y. Size effects of imidazolium cations bearing cyanoethyl group on performance of dye-sensitized solar cells. Mater. Lett. 2019, 246, 137-140. [CrossRef]

40. Dhar, A.; Kumar, N.S.; Asif, M.; Vekariya, R.L. Pyridinium-clubbed dicationic ionic liquid electrolytes for efficient next-generation photo harvesting. New J. Chem. 2018, 42, 6990-6996. [CrossRef]

41. Chen, J.; Peng, T.; Fan, K.; Xia, J. Iodine-free quasi solid-state dye-sensitized solar cells based on ionic liquid and alkali salt. J. Mater. Chem. 2011, 21, 16448-16452. [CrossRef]

42. Syairah, A.; Khanmirzaei, M.H.; Saidi, N.M.; Farhana, N.K.; Ramesh, S.; Ramesh, K.; Ramesh, S. Effect of different imidazolium-based ionic liquids on gel polymer electrolytes for dye-sensitized solar cells. Ionics 2019, 25, 2427-2435. [CrossRef]

43. Li, Q.; Tang, Q.; He, B.; Yang, P. Full-ionic liquid gel electrolytes: Enhanced photovoltaic performances in dye-sensitized solar cells. J. Power Sources 2014, 264, 83-91. [CrossRef]

44. Yamanaka, N.; Kawano, R.; Kubo, W.; Masaki, N.; Kitamura, T.; Wada, Y.; Watanabe, M.; Yanagida, S. Dye-Sensitized $\mathrm{TiO}_{2}$ Solar Cells Using Imidazolium-Type Ionic Liquid Crystal Systems as Effective Electrolytes. J. Phys. Chem. B 2007, 111, 4763-4769. [CrossRef]

45. Pan, X.; Wang, M.; Fang, X.; Zhang, C.; Huo, Z.; Dai, S. Ionic liquid crystal-based electrolyte with enhanced charge transport for dye-sensitized solar cells. Sci. China Chem. 2013, 56, 1463-1469. [CrossRef]

46. Hwang, D.; Kim, D.Y.; Jo, S.M.; Armel, V.; MacFarlane, D.R.; Kim, D.; Jang, S.Y. Highly efficient plastic crystal ionic conductors for solid-state Dye-Sensitized solar cells. Sci. Rep. 2013, 3, 3520. [CrossRef] [PubMed]

47. Chi, W.S.; Ahn, S.H.; Jeon, H.; Shul, Y.G.; Kim, J.H. Rubbery copolymer electrolytes containing polymerized ionic liquid for dye-sensitized solar cells. J. Solid State Electrochem. 2012, 16, 3037-3043. [CrossRef]

48. Su'ait, M.S.; Rahman, M.Y.A.; Ahmad, A. Review on Polymer Electrolyte in Dye-Sensitized Solar Cells (DSSCs). Sol. Energy 2015, 115, 452-470. [CrossRef]

49. Kambe, S.; Nakade, S.; Kitamura, T.; Wada, Y.; Yanagida, S. Influence of the electrolytes on electron transport in mesoporous $\mathrm{TiO}_{2}$-electrolyte systems. J. Phys. Chem. B 2002, 106, 2967-2972. [CrossRef]

50. Ruff, I.; Friedrich, V.J. Transfer Diffusion. I. Theoretical. J. Phys. Chem. 1971, 75, 3297-3302. [CrossRef]

51. Ruff, I.; Friedrich, V.J.; Demeter, K.; Csillag, K. Transfer diffusion. II. Kinetics of electron exchange reaction between ferrocene and ferricinium ion in alcohols. J. Phys. Chem. 1971, 75, 3303-3309. [CrossRef]

52. Ruff, I.; Botár, L. Effect of exchange reactions on transport processes: A comparison of thermodynamic treatment with random walk on lattice points. J. Chem. Phys. 1985, 83, 1292-1297. [CrossRef]

53. Lee, S.A.; Jackson, A.S.; Hess, A.; Fei, S.; Pursel, S.M.; Basham, J.; Grimes, C.A.; Horn, M.W.; Allcock, H.R.; Mallouk, T.E. Influence of different iodide salts on the performance of dye-sensitized solar cells containing phosphazene-based nonvolatile electrolytes. J. Phys. Chem. C 2010, 114, 15234-15242. [CrossRef]

54. Wang, P.; Zakeeruddin, S.M.; Moser, J.E.; Humphry-Baker, R.; Grätzel, M. A Solvent-Free, $\mathrm{SeCN}^{-} /\left(\mathrm{SeCN}_{3}{ }^{-}\right.$ Based Ionic Liquid Electrolyte for High-Efficiency Dye-Sensitized Nanocrystalline Solar Cells. J. Am. Chem. Soc. 2004, 126, 7164-7165. [CrossRef]

55. Koi, Z.K.; Yahya, W.Z.N.; Abu Talip, R.A.; Kurnia, K.A. Prediction of Viscosity of Imidazolium-based Ionic Liquids at Different Temperatures using Quantitative Structure Property Relationship Approach. New J. Chem. 2019, 43, 16207-16217. [CrossRef]

56. Docampo, P.; Guldin, S.; Leijtens, T.; Noel, N.; Steiner, U.; Snaith, H. Lessons Learned: From Dye-Sensitized Solar Cells to All-Solid-State Hybrid Devices. Adv. Mater. 2014, 26, 4013-4030. [CrossRef] [PubMed]

(C) 2020 by the authors. Licensee MDPI, Basel, Switzerland. This article is an open access article distributed under the terms and conditions of the Creative Commons Attribution (CC BY) license (http://creativecommons.org/licenses/by/4.0/). 